\title{
News for Educational Workers
}

\author{
by Leonard Vogt
}
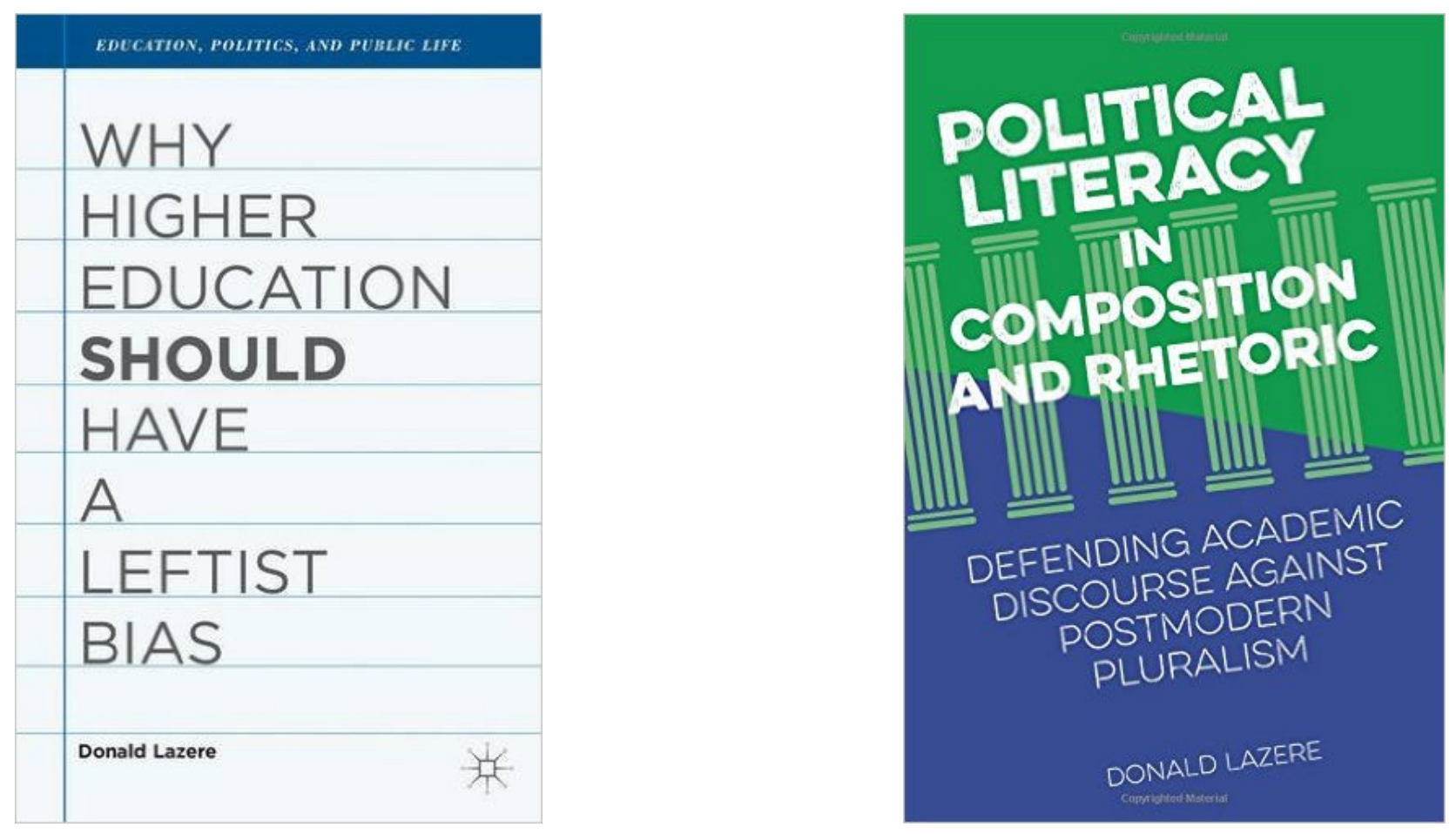

Presenting a thoughtful justification for the left in American education, Donald Lazere's Why Higher Education Should Have a Leftist Bias (Palgrave) argues that to teach students rhetoric and critical thinking, key components of a humanist education, educators must discuss and teach students to grapple with the conservative bias in academia, the media, and politics that is considered to be the status quo.

In Political Literacy in Composition and Rhetoric: Defending Academic Discourse Against Postmodern Pluralism (SIU Press), Donald Lazere calls for revival of the National Council of Teachers of English resolutions in the 1970s for teaching the "critical reading, listening, viewing, and thinking skills necessary to enable students to cope with the persuasive techniques in political statements, advertising, entertainment, and news," and explores the reasons these goals have been eclipsed in composition studies over recent decades. 


\section{Unions and Strikes}

The faculty union of The City University of New York (CUNY) voted overwhelmingly (92 percent of over 10,000 unionized faculty and staff members voting in favor) for strike authorization to be used possibly in the fall in the union's continuing efforts to get a contract after five years. Even though CUNY faculty have not had a pay raise in 6 years (over which time the cost of living in New York City went up 23 percent), New York lawmakers a month earlier passed a state budget which included no money for CUNY faculty pay increases (The Chronicle of Higher Education, May 12, 2016).

On February 24, 2016, graduate workers at the Missouri University occupied the university's administrative building to demand that they be recognized as university employees and be given collective bargaining rights (Left Labor Reporter, February 26, 2016).

"The Union Advantage for Contingent Faculty" says that union representation over a 30-year career can mean an additional salary of at least $\$ 1$ million for a full-time professor at public universities. For adjuncts as well, who make an average of $\$ 2,700$ per course which adds up to a yearly salary of $\$ 22,000$ for four courses a semester, union representation could help relieve their poverty conditions. When adjuncts have won union rights, they work under one to three year contracts and earn $\$ 7,300$ per course, making their annual salary almost $\$ 60,000$ for four courses a semester (The New Crossroads, April 27, 2016).

The Working Educators (WE), the progressive caucus of the Philadelphia Federation of Teachers (PFT), initiated a campaign last year to inform Philadelphia parents and teachers about their right to "Opt Out" of standardized tests because the PFT leaders were not talking about the demoralizing aspects of overtesting on students, teachers or parents (www.truth-out.org, January 29, 2016).

The Chicago Teachers Union held a one-day strike and citywide day of action on April 1, 2016. According to Jacobin (April 2, 2016), the strike was not "primarily about increased school funding, pensions for teachers, or even corporate taxation, though the union is fighting for all of these. It is a strike about democracy-about who owns our society's resources and how decisions about those resources are made." Those supporting the strike were transit workers union ATU 308, AFSCME Council 31, the Black Youth Project 100, University Professionals of Illinois Local 4100 and the Chicago Student Union.

In February and March of 2016, an estimated 20,000 teachers, nearly half the entire Palestinian teaching staff, defied the Palestinian Authority (PA), went on a wildcat strike, and won a pay raise they were promised three years earlier. Many of the demonstrators, some of whom were treated brutally by the PA in its attempt to keep them away from the strike, feel that the teachers' union leadership's close tie to the government is a detriment to teachers' rights (portside.org, May 1, 2016).

A Colombian academic and member of the higher education union ASPU, Dr. Miguel Ángel Beltrán, was arrested for rebellion in July, 2015, sentenced to 8 years in a high security prison, and is now on hunger strike to demand that his case be reviewed. To send a message of protest to the Colombian government, go to http://www.labourstart.org/go/beltran.

\section{Student Activism}

The national "Fossil Free" movement is pressuring colleges to address the issue of climate change by divesting from fossil fuels. In April of 2016, 8 students at Northern Arizona University were arrested during a sit-in. At Columbia University, a six-day occupation of Low Library was held to demand the president of the university endorse fossil fuel divestment. This occupation gained supporting praise from presidential candidate Bernie Sanders (democracynow.org, April 20 and 29, 2016).

Linda Katehi, the chancellor of University of California, Davis, was put on administrative leave during an investigation of a number of infractions, including the 2011 pepper-spraying of student protestors and her subsequent $\$ 175,000$ attempt to get the viral video off the internet. Protesting students also demanded she resign her position on private corporations such as the for-profit DeVry University, the textbook publisher Wiley \& Sons, and the Saudi school King Abdulaziz University (democracynow.org, March 17 and 29, 2016).

The University of Puerto Rico was shut down during a three-day student strike in protest of austerity cuts (democracynow.org, March 17, 2016).

The Million Student March of November 12, 2015 marks the beginning of the student movement demanding free higher education, cancellation of all student debt, and a $\$ 15$ minimum wage for all campus workers. Over 100 actions have been carried out across the country with support from numerous progressive organizations and labor unions. To read about the history and future of this movement, see "Why Free Higher Ed Can't Wait: Students are Rising Up to Demand Free Higher Education" (Dollars \& Sense, March/April, 2016).

According to the Center for American Progress, 65,000 undocumented students graduate from high school every year and large numbers of them are involved in breaking barriers for accessing higher education and fighting for immigrant rights. To read the story of just one of these students, go to www.truth-out.org, January 3, 2016.

\section{$\mathrm{K}-12$}

Detroit teachers have been calling in sick to make their grievances heard. One of these "sickouts" helped force Darnell Earley to resign as emergency manager of Detroit Public Schools. As emergency manager of Flint, Michigan, Earley is well known for his infamous switching of water supplies, resulting in the poisoning of Flint's water. The largest such "sickout" action of January 20, 2016 temporarily closed 88 of the district's 104 schools. And again in May, 2016 all but three of the city's public schools were closed due to a "sickout" over the possibility of the 
district running out of money and teachers not getting paid at the end of the school year (In These Times, April, 2016; democracynow.org, May 3, 2016).

Across the country, and disproportionately with students of color or students with disabilities, discipline frequently comes in the form of paddles, stun guns and mace, thus allowing police departments to criminalize adolescent conflict (truth-out.org, March 12, 2016). Even before entering their classrooms, 100,000 New York City school children must go through airport-style security screening every day (portside.org, January 16, 2016).

In March 2016 over 2,000 students from the Boston Public Schools walked out in protest over austerity measures and the proposed $\$ 50$ million deficit for the following year (portside.org, March 9 and 14, 2016).

"Teacher Challenges Low Evaluation in Court and Wins" (Washington Post, May 10, 2016) describes how Sheri Lederman, a fourth-grade teacher in Great Neck, New York, won her legal battle to have her 2013-14 VAM score of "ineffective" removed by the Supreme Court of New York State. The case, argued by Lederman's lawyer husband, made the Justice who heard the case declare the score "arbitrary" and "capricious" as he declared it illegal. This case is an inspiration for other teachers to stand up and legally challenge their scores and thus challenge the validity of the testocracy.

Teachers are often humiliated, frequently pessimistic, and even sometimes hopeful as the profession faces the $21^{\text {st }}$ century challenges of the U.S. educational system. "Stop Humiliating Teachers" (The New Yorker, February 11, 2016) describes the U.S. "tendency, when there's an economic or social crisis, to lay blame on public school teachers. They must have created the crisis, the logic goes, by failing to educate the young." In "Professor: Why I am 'Incredibly Pessimistic' About the Future of Public Education" (Washington Post, March 11, 2016), Mark Naison explains his pessimism: "Public schools in recent years have sustained assaults from believers in the privatization of the public education system. The powers that be plan a data-based reinvention of teacher education that will require the closing, or reinvention of colleges of teacher education. If these plans go through, a majority of the nation's teachers and teacher educators could lose their jobs in the next 10 years, replaced by people who will largely be temp workers making minimum wages." And Henry Giroux explains "Why Teachers Matter in Dark Times" (truth-out.org, May 13, 2016): "For the most part, public school teachers and higher education faculty are a national treasure and may be one of the last defenses available to undermine a growing authoritarianism, pervasive racism, permanent war culture, widening inequality and debased notion of citizenship in US society. They can't solve these problems but they can educate a generation of students to address them. Yet, public school teachers, in particular, are underpaid and overworked, and lack adequate resources. In the end, they are unjustly blamed by right-wing billionaires and politicians for the plight of public schools. In order to ensure their failure, schools in many cities, such as Detroit and Philadelphia, have been defunded by right-wing legislators. These schools are dilapidated-filled with vermin and broken floors-and they often lack heat and the most basic resources. They represent the mirror image of the culture of cruelty and dispossession produced by the violence of neoliberalism."

\section{Race and Education}

According to a report by the Atlantic Black Star, Black students in the South are twice as likely to receive corporal punishment as white students, with 42,000 Black male students reporting that they were beaten. Data compiled by the U. S. Department of Education shows that Black students are three times more likely than white students to be suspended or expelled from school. Nationwide 15 percent of Black students receive suspensions compared with 4 percent of white students (truth-out.org, April 9, 2016).

For White Folks Who Teach in the Hood . . . and the Rest of Y'all Too by Chris Emdin of Columbia's Teachers College critiques the pervasive savior complex narrative that gives white teachers in minority and urban educational communities a false sense of saving students. Emdin compares this approach to the Native American schools of the past that measured success by how well students adapted to forced assimilation and encourages contemporary teachers to value the unique realities of minority children and incorporate their cultures into classroom instruction (portside.org, April 16, 2016).

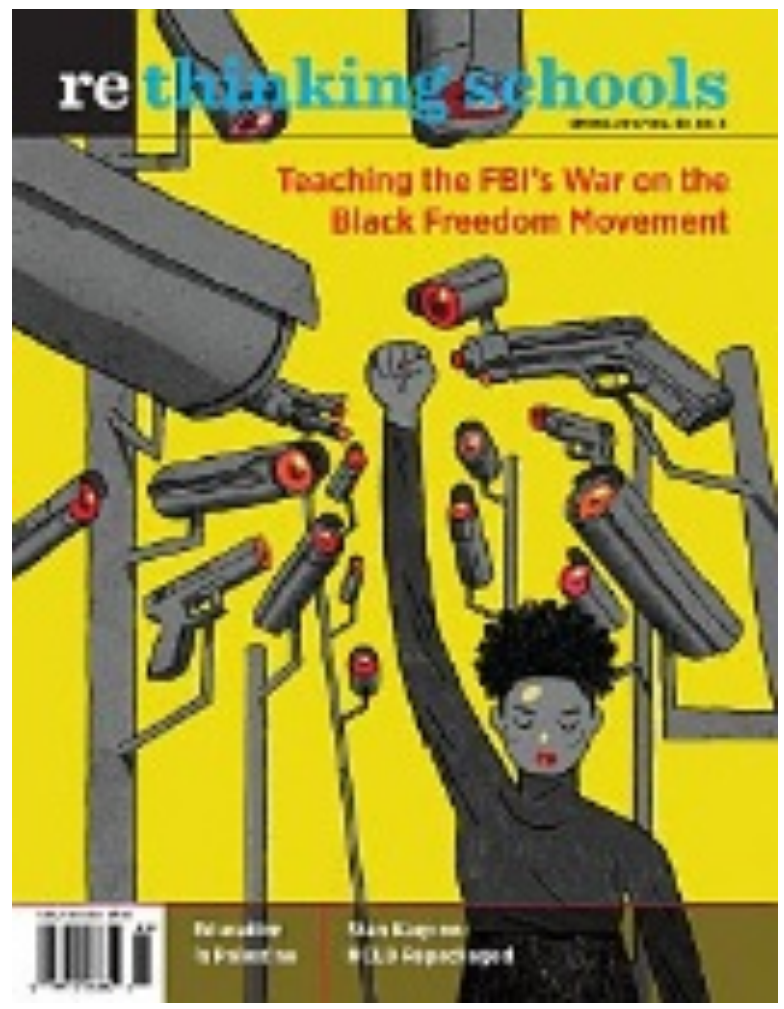

Rethinking Schools (Spring 2016, Vol. 30, No. 3) continues its excellent educational reporting with a feature article "Teaching the FBI's War on the Black Freedom Movement." At Lake Oswego High School in Oregon, 
students learn about the FBI's counterintelligence program of the 1960s and 70s and make connections with the Black Lives Matter movement of today.

The Afrikan Black Coalition ( $A B C$ ) of the University of California (UC), after months of research and pressure against UC's complicity in the prison-industrial complex, announced that UC has begun to sell all its shares in private prisons (portside.org, January 14, 2016).

As students confront racism on U. S. campuses, they also are learning about the legacy of segregation and the history of the Black Freedom Movement. At Middle Tennessee State University, students are demanding the renaming of Forrest Hall named after a Confederate general and the KKK's first grand wizard. At Princeton University, students want the Woodrow Wilson School of Public and International Affairs and the Wilson College residential complex renamed because of Wilson's aggressive support of segregation (portside.org, January 8 and February 27, 2016).

\section{Charter Schools}

The Miami Herald reports that Florida since 2000 has given $\$ 70$ million in taxpayers' money to charter schools that have closed down in 30 school districts. The Department of Education says it has gotten back only $\$ 133,000$ in the last three years from the schools that closed.

"'Got to Go': High-Performing Charter Schools Shed Students Quickly" (The Guardian, February 21, 2016) focuses on Success Academy, the largest charter school network in New York City, which achieves high test scores by driving low performers out, at a rate almost four times as high as at public schools (10\% versus $2.7 \%)$.

Jacobin (April 2016) gives the history of the charter school movement in Chicago and how it closed neighborhood schools.

\section{Israel, Palestine, and Divestment}

Students and faculty across the country are joining the boycott against Israel for violations of Palestinian human rights by encouraging their universities to divest from Israeli state institutions and corporations that do business in the Israeli-occupied Palestinian territories. The New York University graduate study union voted overwhelmingly to boycott (salon.com, April 23, 2016). At the University of Wisconsin-Madison, the 9,000 member graduate study union voted to join the Boycott, Divestment and Sanctions (BDS) movement (democracynow.org, May 19, 2016). The Columbia University faculty signed a petition supporting divestment. On January 7, 2016, the Cleveland, Ohio chapter of Jewish Voice for Peace unanimously endorsed the Emergency Resolution on Islamophobia submitted by the Radical Caucus of the Modern Language Association submitted at the 2016 MLA Convention in Austin, Texas. The Radical Caucus has been trying to introduce a BDS resolution but has faced strong opposition for several years.
Reactions to boycott and divestment have not always been sympathetic. Harvard Law School's Justice for Palestine group received funds from The Milbank Fund, the multinational law firm that endowed it, for a speaker event called "The Palestine Exception to Free Speech: A Movement Under Attack" where speakers addressed the widespread suppression of Palestinian rights advocacy in the United States, with reference to the de-tenuring of Steven Salaita at the University of Illinois. The next day, the Dean of Students office received many angry phone complaints from Milbank executives who wanted the name of their fund to be removed from any future events of the Justice for Palestine group (The Harvard Law Record, February 17, 2016). According to www.theintercept.com (March 24, 2016), the regents of the University of California unanimously adopted a new "discrimination" policy that links anti-Zionism to anti-Semitism. The logic was that "students opposed to Israeli policies, and those questioning the state's unequal treatment of non-Jews, had fostered a dangerous environment for Jewish students by supporting the effort to pressure Israel to change its policies through a campaign of boycotts, divestment and sanctions, known as BDS." And in Florida, state legislatures voted in a bill that would eliminate state funding from groups, including universities, associated with BDS, a bill that sets a precedent for defunding in other states where BDS activity is strong in universities (truthout.org, February 25, 2016).

"Why Israel's Schools Merit a US Boycott" (Los Angeles Times, January 8, 2016) explains the relationship between Israel's educational system and what the article terms, "its broader structures of racism." As an example, the article states that Israel maintains two separate educational systems for Jewish children and for minority Palestinian children, with three times more money being invested in the education of a Jewish as opposed to a Palestinian student.

At The Palestinian Technical University Kadoorie in Tulkarem, an agricultural institution, the Israeli army has confiscated land to use for military training and as a shooting range. Opposing this militarization of the campus is the "Friends of Kadoorie" campaign which can be reached at friendsofkadoorie@gmail.com (Academia for Equality, Kadoorie University).

\section{Sexuality, Gender, and Education}

"83 Seconds" (The Nation) states "Women are currently receiving less than a fifth of all bachelor's degrees in physics, computer science, and engineering." Why? Since we know girls and women are just as intelligent and adaptable as boys and men, and indeed females get better grades than males in high school and college mathematics courses, there must be another answer. Marcia Linn of UC Berkeley explains that testing is the problem since girls and women are far better course takers while boys and men are better test takers. Linn explains that "the tendency of girls [is] to be more conscientious than boys," when taking tests, thus pondering more over 60 second answers (or even the more generous 83 seconds now 
allotted by the SAT) than boys do and ending up with fewer correct answers and lower overall scores.

Rethinking Schools (Winter 2015-16, Vol. 30, No. 2) highlights two cover stories on "Rethinking Sexism, Gender, and Sexuality," one story describing a New York City K-8 school welcoming a transgender $8^{\text {th }}$ grader and the gender transition of another student, and the second story showing how a $9^{\text {th }}$ grade teacher teaches a sex-positive and inclusive sex education class.

\section{Religion and Education}

Title IX, the law prohibiting sex discrimination, is structured in such a way that exemption can be requested by religiously affiliated schools and programs, institutions and places where sex discrimination might indeed be most prevalent. Religious schools that receive federal dollars may ignore federal law Title IX, as 56 of them have since 2013 by getting exemptions (The Nation, February 8, 2016 and truth-out.org, April 2, 2016).

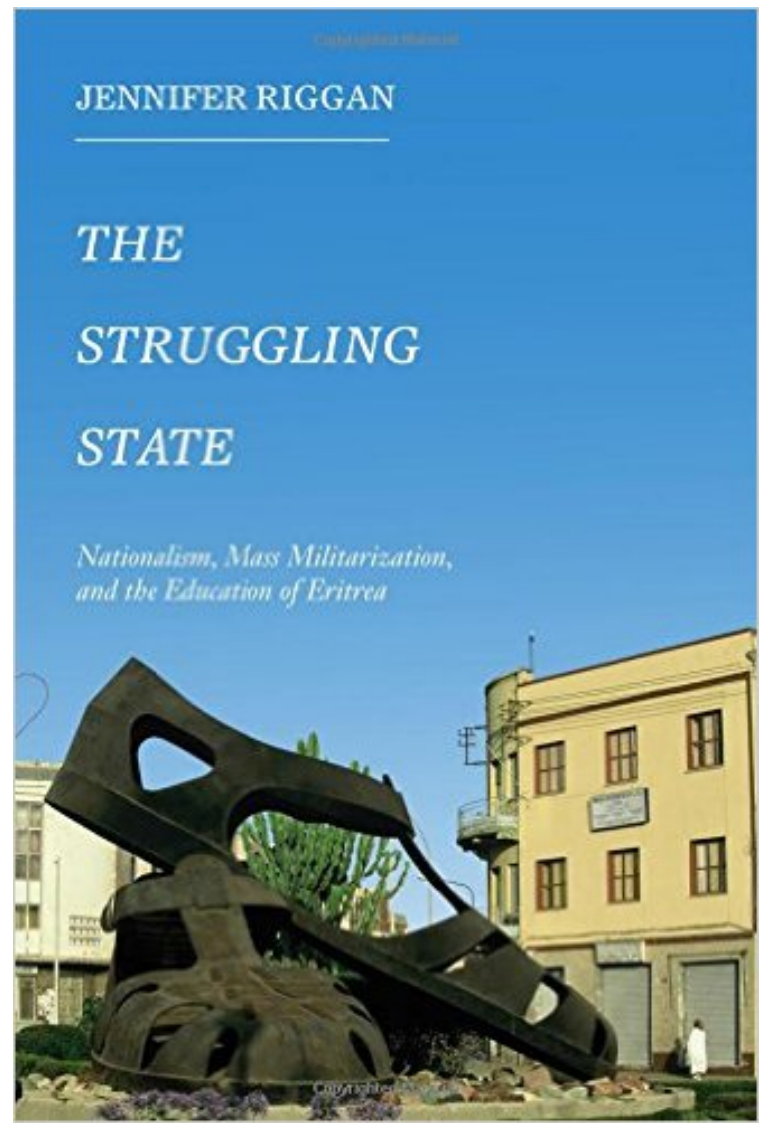

\section{Resources}

In The Struggling State, Jennifer Riggan examines the contradictions of state power in Eritrea as simultaneously oppressive to and enacted by teachers. Riggan, who conducted participant observation with teachers in and out of schools, explores the tenuous hyphen between nation and state under lived conditions of everyday authoritarianism. A 2003 law in Eritrea-a notoriously closed-off, heavily militarized, and authoritarian countrymandated an additional year of school for all children and stipulated that the classes be held at Sawa, the nation's military training center. As a result, educational institutions were directly implicated in the making of soldiers, putting Eritrean teachers in the untenable position of having to navigate between their devotion to educating the nation and their discontent with their role in the government program of mass militarization. The Struggling State shows how the hopes of Eritrean teachers and students for the future of their nation have turned to a hopelessness in which they cannot imagine a future at all.

Bullfrog Films has released three new videos to be used in high school and college classrooms.

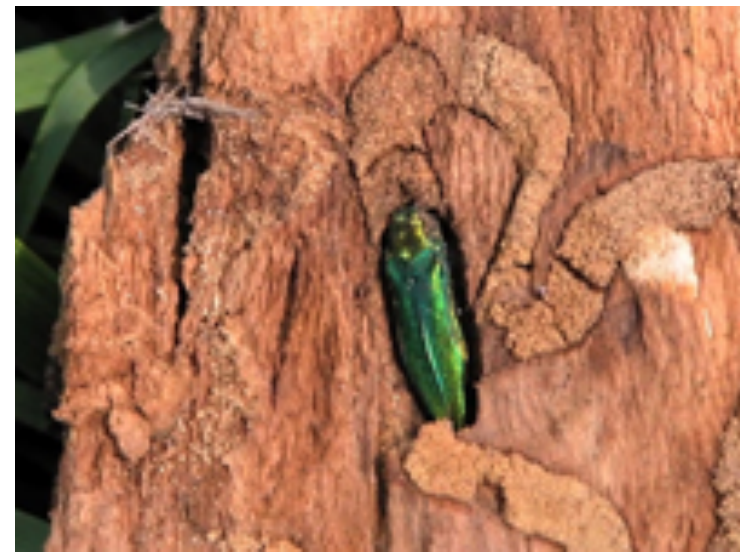

TREES IN TROUBLE: Saving America's Urban Forests tells the compelling story of how one community in southwest Ohio confronted their tree crisis and fought the invasive pest by taking action and joining together. Through partnerships with scientists, city officials and everyday citizens, this community was able to fight the pest and protect their urban forests for future generations. The film also explores the rich history of urban forestry in the United States and the exciting new research linking human health and trees.

As world governments struggle to meet the aspirational limit of $1.5^{\circ} \mathrm{C}$ of global warming agreed to at COP21 in Paris, a new campaign is targeting the fossil fuel industry in an effort to withdraw its social license to operate. DIVEST!: The Climate Movement on Tour chronicles 350.org's 'Do the Math' bus tour across the United States in 2012 as it launched the fossil fuel divestment campaign onto the national and ultimately international stage.

WEconomics: Italy reports on the extensive and innovative cooperative economy in the region around Bologna. The Emilia-Romagna region in northern Italy has one of the highest concentrations of cooperative businesses in the developed world. The capital, Bologna is an industrial powerhouse, where prosperity is widely shared, and cooperatives of teachers and social workers play a key role in the provision of government services. 
Is there a news item, call for papers, upcoming conference, resource, teaching tool, or other information related to progressive education that you would like to share with other Radical Teacher readers? Conference announcements and calls for papers should be at least six months ahead of date. Items, which will be used as found appropriate by Radical Teacher, cannot be returned. Send hard copy to Leonard Vogt, Department of English, LaGuardia Community College (CUNY), 31-10 Thomson Avenue, Long Island City, New York 11101-or email items tolvogt@nyc.rr.com. 